\title{
Histoplasmosis Infections Worldwide: Thinking Outside of the Ohio River Valley
}

\author{
Nathan C. Bahr ${ }^{1,2} \cdot$ Spinello Antinori $^{3} \cdot$ L. Joseph Wheat ${ }^{4} \cdot$ George A. Sarosi $^{2,5}$
}

Published online: 11 April 2015

(C) Springer International Publishing AG 2015

\begin{abstract}
In the USA, histoplasmosis is generally thought to occur mainly in the Ohio and Mississippi river valleys, and the classic map of histoplasmosis distribution reflecting this is second nature to many US physicians. With the advent of the HIV pandemic, reports of patients with progressive disseminated histoplasmosis and AIDS came from regions of known endemicity, as well as from regions not thought to be endemic for histoplasmosis throughout the world. In addition, our expanding armamentarium of immunosuppressive medications and biologics has increased the diagnosis of histoplasmosis worldwide. While our knowledge of areas in which
\end{abstract}

This article is part of the Topical Collection on Tropical Mycosis

iThenticate: $6 \% \mathrm{ok}$

Nathan C. Bahr

bahrx026@umn.edu

Spinello Antinori

spinello.antinori@unimi.it

L. Joseph Wheat

jwheat@miravistalabs.com

George A. Sarosi

George.Sarosi2@va.gov

1 Division of Infectious Diseases and International Medicine, Department of Medicine, University of Minnesota, MMC 250, 420 Delaware St. S.E., Minneapolis, MN 55455, USA

2 Department of Medicine, University of Minnesota, Minneapolis, MN, USA

3 Department of Clinical and Biomedical Sciences, "Luigi Sacco," III Division of Infectious Diseases, University of Milano, Via GB Grassi 74, 20157 Milan, Italy

4 MiraVista Diagnostics, 4705 Decatur Blvd, Indianapolis, IN 46241, USA

5 Department of Medicine, Minneapolis Veterans Affairs Medical Center, One Veterans Drive, Minneapolis, MN 55417, USA histoplasmosis is endemic has improved, it is still incomplete. Our contention is that physicians should consider histoplasmosis with the right constellations of symptoms in any febrile patient with immune suppression, regardless of geographic location or travel history.

Keywords Histoplasmosis · Progressive disseminated histoplasmosis · Pulmonary fungal infections $\cdot$ Human immunodeficiency virus - Acquired immunodeficiency syndrome $\cdot$ Immunosuppression $\cdot$ Infectious diseases, emerging, travelers $\cdot$ Biologic drugs $\cdot$ Histoplasma capsulatum var. capsulatum $\cdot$ H. capsulatum var. duboisii

\section{Introduction}

Histoplasmosis, in the USA, is primarily seen in the Ohio and Mississippi river valleys [1]. The narrative regarding histoplasmosis is supported by solid epidemiologic evidence. By the midtwentieth century, a geographic clustering of patients with histoplasmosis was noted [2], and mapping of reactive histoplasmin skin tests was employed in patients with pulmonary calcifications on chest radiographs who did not react to tuberculin skin testing [3]. Edwards and colleagues constructed the now quite-familiar map of histoplasmin skin reactivity among naval recruits [4].

While the central USA seemed to have the greatest prevalence of Histoplasma capsulatum var. capsulatum, Brazil [5], Argentina [6], India [7], and South Africa [8] have all reported small case series, and Histoplasma capsulatum var. duboisii was thought to exist predominantly in West Africa. Additionally, sporadic cases have been reported from Central and South America, Oceania, northern sub-Saharan Africa, and Europe [6]. Histoplasmin skin-test sensitivity analyses showed fairly high levels throughout Central America and 
parts of South America as well as Puerto Rico, Dominica, and Mexico in addition to the central USA with almost no skin-test sensitivity in Europe, and scant information available from the rest of the world [6]. These skin-test surveys appeared to support the idea that histoplasmosis exposure was infrequent in the rest of the world.

Over a number of years over which the authors have gained experience at multiple centers around the USA and Italy, it is extremely common for trainees at all stages to make assumptions about whether a diagnosis is even possible based on the geographical location alone. This review will focus on the truly global nature of histoplasmosis while acknowledging that the infection is certainly more common in certain areas and that our current knowledge of endemicity is incomplete.

\section{Pathogenesis and Immunity}

The portal of entry for H. capsulatum is the lung, and following inhalation, an area of pneumonitis develops. Neutrophils are unable to destroy the organism, although macrophages can ingest but cannot destroy the fungus [9]. Initially, during the pre-immune phase, the fungus disseminates widely throughout the body [9]. Once T cell-mediated immunity develops, the entire process is arrested and recovery occurs [9] - this allows for most infections to go unnoticed in persons without immune deficits. Primary infection by $H$. capsulatum is predominantly asymptomatic [9]; however, in patients exposed to a large infecting inoculum, symptomatic pulmonary infection is more common, and many patients require hospitalization [10].

The degree to which infection is often subclinical is illustrated well by a 1964 outbreak in Mason City, Iowa. Of the estimated 6000 predominantly asymptomatic infections, only 1 person developed progressive disseminated histoplasmosis and 87 persons developed acute pulmonary histoplasmosis [11]. This attack rate in the context of the estimated number of subclinical infections was possible because an outbreak 2 years prior allowed for serial skin testing.

In patients with faulty $\mathrm{T}$ cell-mediated immunity, this localized containment does not occur and progressive dissemination may take place, leading to clinical illness [9]. Faulty T cell-mediated immunity may be innate (e.g., Job syndrome, severe combined immunodeficiency syndrome, etc.), caused by immunosuppressive medications or may be caused by immunodeficiency states related to other diseases such as malignancy or HIV infection [9]. Inadequate T cell function allows progressive disseminated histoplasmosis due to reactivation of previous infection among patients with new immune compromise and has been particularly noted among immigrants from Latin America and sub-Saharan Africa in nonendemic geographic locales in Europe $[12,13]$. Further evidence of the importance of $\mathrm{T}$ cell function in controlling Histoplasma infection was provided in a recent retrospective analysis of $\sim 1400$ HIV-infected persons in French Guiana in which the authors found a hazard ratio for the development of progressive disseminated histoplasmosis of 47.2 in patients with CD4 $\mathrm{T}$ lymphocyte counts of $0-50$ cells $/ \mu \mathrm{L}$, as compared to $>500$ cells $/ \mu \mathrm{L}$, with an inverse relationship continuing between CD4 count and hazard ratio at higher CD4 counts [14•]. Table 1 reviews the more typical clinical manifestations of $H$. capsulatum infection as well as associated risk factors. Treatment varies by infection type [1-13, 14•, 15-18].

\section{Global Histoplasmosis and the Advent of AIDS}

In 1983, several patients who had been diagnosed with AIDS and progressive disseminated histoplasmosis were reported [19-23]. While one report came from a known hyperendemic area for histoplasmosis in Indiana [22], other reports came from areas in the USA (Texas, Michigan) where histoplasmosis was less common $[19,21]$ or had not been thought to be present (New York, Colorado) [20, 23]. These reports rapidly increased across the USA in endemic and non-endemic areas alike [24, 25]. In addition, patients from around the world were reported from areas where histoplasmosis had been rarely or never reported such as Trinidad [26], Thailand [27], and the Democratic Republic of Congo [28]. By 1990, Wheat and colleagues noted $>100$ cases of histoplasmosis in persons with AIDS [29], and although many came from Indiana, a sizeable minority were from areas outside of traditional endemic zones. Most of the reported symptomatic cases were patients with progressive disseminated histoplasmosis [29], as opposed to isolated pulmonary infections as had been the most common presentation in HIV-uninfected patients (when the infection did indeed lead to symptomatic clinical illness). In the decades since, numerous case series of progressive disseminated histoplasmosis associated with HIV infection have been reported around the globe in locations with few, if any, previously reported cases [30].

The widespread reporting of patients with progressive disseminated histoplasmosis since the advent of AIDS helped to identify previously unrecognized endemic areas where a great number of subclinical infections must have occurred but were not previously recognized. Similarly, for known outbreaks of histoplasmosis (including those reported in persons with AIDS), likely many more, subclinical, infections occur.

Ideally, antiretroviral therapy (ART) is started before immunocompromised occurs in HIV-infected persons and reverses the immune defect, reducing the likelihood of development of histoplasmosis. The idea of prevention is supported by a 2001 case-control study in which patients were matched for CD4 count among other factors - patients on ART had less risk all for developing disseminated histoplasmosis, even at low CD4 counts [31]. Interestingly, there have been reports of 
Table 1 Major clinical manifestations of histoplasmosis and associated risk factors

\begin{tabular}{ll}
\hline Manifestation & Risk factors \\
\hline $\begin{array}{l}\text { Acute pulmonary histoplasmosis } \\
\text { Chronic pulmonary histoplasmosis }\end{array}$ & $\begin{array}{l}\text { Young age, exposure to a large inoculum of Histoplasma } \\
\text { Older age, chronic obstructive lung disease related to tobacco } \\
\text { use } \\
\text { Mediastinal lymphadenitis, granuloma, fibrosis } \\
\text { Young age undefined inflammatory or immunologic factors } \\
\text { in mediastinal fibrosis }\end{array}$ \\
Pericarditis or rheumatologic syndrome & $\begin{array}{l}\text { Young age, immunocompetence, male sex, and African } \\
\text { American race in pericarditis and female sex in }\end{array}$ \\
roumatologic syndromes \\
rogressive disseminated histoplasmosis & An immunocompromising condition or medication, primary \\
& or acquired immunodeficiency, age $<1$ or $>55$ years \\
\hline
\end{tabular}

The table above notes major categories of histoplasmosis and risk factors associated with the development of this type of disease related to histoplasmosis otherwise untreated histoplasmosis in persons with AIDS improving with ART alone [32]. In many high-income countries, guidelines recommend that all HIV-infected persons are started on ART regardless of CD4 count [33], and so, advanced immune suppression related to HIV infection and opportunistic infections such as histoplasmosis is less frequent in these countries. However, in many parts of the world, ART access is still not adequate and more cases of disseminated histoplasmosis are likely.

While AIDS illuminated many areas of hidden histoplasmosis endemicity, cases in areas not previously known to be endemic are still being reported and our knowledge regarding the distribution of histoplasmosis is expanding. With the incomplete nature of our understanding in mind, the reminder of the review will focus on the worldwide distribution of histoplasmosis and factors that might influence our understanding of histoplasmosis distribution in the future as HIV has done in the past and continues to do.

\section{Global Distribution of Histoplasmosis}

Our present knowledge of the worldwide distribution of Histoplasma capsulatum var. capsulatum relies most on the histoplasmin skin-test surveys with additional information coming from soil isolation of the fungus. Many of the pertinent studies were conducted in the 1950s-1970s [6, 34, 35]. Notably, a summary of skin-test studies by Mochi and Edwards in 1952 [6] highlighted that the "highest prevalence of histoplasmin sensitivity is found in east-central part of the USA, in southern Mexico, Central America and certain parts of South America. An isolated, low sensitivity area has been reported from South Africa [6], and almost no histoplasmin sensitivity has been found in Europe, with the possible exception of Italy" [6]. Much of Asia and nearby nations was excluded from their "preliminary attempt" to map the geographical distribution of histoplasmosis due to the lack of any data from these areas [6].
A review regarding soil isolation of $H$. capsulatum written in 1964 by Libero Ajello, added that in addition to wellknown endemic areas such as North America (USA, Mexico), Central America (Panama), and South America (Brazil, French Guiana, Perù, and Venezuela), a few countries in Africa (Congo, Tanzania, and South Africa's Guateng and Limpopo provinces), Asia (Malaysia), and the Caribbean (Trinidad) [36] also housed H. capsulatum within their borders.

It is worth noting that, until now, the geopolitical isolation of several countries as well as the lack of microbiological facilities in many low-income areas of the world might have contributed to the difficulty in constructing an accurate map of worldwide histoplasmosis distribution. Table 2 shows studies from outside the USA [37-59], while Fig. 1 shows a world map constructed with estimated areas endemic to histoplasmosis based on case reports primarily among HIV-infected patients.

An important example of a country in which the increasing rate of infections has been recognized in recent years is China. A 2013 review found that from 1990 to 2011, 300 cases were reported in China of which $75 \%$ occurred along the Yangtze river $[60 \bullet$ ]. Progressive disseminated histoplasmosis occurred in 257 of the 300 cases and immune suppression, HIV in most cases, was present in most patients [60••]. Studies from China report the prevalence of histoplasmin skin-test reactivity ranging from 6 to $50 \%[37,53,54]$. Interestingly, the distribution of $H$. capsulatum overlaps that of Penicillium marneffei [61] in several areas of China.

The occurrence of histoplasmosis in Asia has not been fully appreciated until recent years despite the fact that in 1970, Randhawa reviewed 30 autochthonous cases from India, Malaysia, Indonesia, Singapore, Thailand, Vietnam, and Japan [54]. Histoplasma has been isolated from the soil from these countries $[62,63]$. Histoplasmin sensitivity was negligible in Japan, except in people working with soil and sand imported from overseas (including the USA) [54], and H. capsulatum has never been isolated from the environment nor detected by PCR in bat guano from Japan [64]. 
Table 2 Areas of endemicity for Histoplasma capsulatum outside United States of America (USA) according to histoplasmin skin reactivity

\begin{tabular}{|c|c|c|}
\hline Country/year/reference & Number tested/population & Histoplasmin skin-test positivity (\%) \\
\hline \multicolumn{3}{|l|}{ Asia } \\
\hline China & 101 & 8.9 \\
\hline Hunan province 2001 [35] & 292/healthy and pulmonary diseases & 16.8 \\
\hline Nanjing district 2001 & 271 healthy students & $6-35$ \\
\hline Sichuan province 1996 [34] & 28 TB patients & \\
\hline India $1955[33]$ & $962 / \mathrm{NR}$ & 1.9 \\
\hline India (Delhi) 1962 & $8062 / \mathrm{NR}$ & 6.8 \\
\hline India (Delhi riverine) 1960 & $162 / \mathrm{NR}$ & 12.3 \\
\hline India (Calcutta) 1954 & $64 / \mathrm{NR}$ & 4.7 \\
\hline India (Calcutta) 1956 & $4855 / \mathrm{NR}$ & 0.7 \\
\hline Malaysia (Kuala Lumpur) 1964 [33] & 227/chest disease patients & 10.5 \\
\hline Myanmar (Rangoon)1952 [33] & $1089 / \mathrm{NR}$ & 27.1 \\
\hline Myanmar (upper region) 1952 & $142 / \mathrm{NR}$ & 8.4 \\
\hline Myanmar (Maguee) 1956 & $154 / \mathrm{NR}$ & 86.4 \\
\hline Philippines (Manila) 1950-1964 [33] & 3878/navy recruits, TB patients, & $4.1-6.4$ \\
\hline Philippines (Luzon island) 2000 [36] & $\begin{array}{l}\text { Medical and nurse students } \\
143 / \text { healthy electric company employees }\end{array}$ & 26 \\
\hline Taiwan (Nantou) 1956 [33] & 444 & 49.8 \\
\hline Thailand (Bangkok) 1967 [33] & 497/medical and nurse students & 5.6 \\
\hline Thailand 1961 & 329/student nurses & 4.0 \\
\hline Thailand (northern region) 1987 & $\mathrm{NR} / \mathrm{NR}$ & $7-14$ \\
\hline Thailand (central region) 1987 & $\mathrm{NR} / \mathrm{NR}$ & $3-9$ \\
\hline Thailand (southern region) 1987 [37] & $\mathrm{NR} / \mathrm{NR}$ & $15-36$ \\
\hline Vietnam (Saigon) $1960[33]$ & $303 / \mathrm{NR}$ & 33.7 \\
\hline \multicolumn{3}{|l|}{ Central and South America } \\
\hline Argentina (Chaco province) 1996 & 315/children & 9.2 \\
\hline Brazil (Minas Gerais state) 1996 [38] & $417 /$ miners & 17.5 \\
\hline Brazil (Rio Grande Do Sul) 1996 [39] & 354/soldiers (17-19 years) & $48-89$ \\
\hline Brazil (Ceara State) 1992 [40] & 138/residents & 61.5 \\
\hline Brazil (Amazonas state) 1978 [41] & 495/residents & 37.8 \\
\hline Colombia (Department of Antioquia) 1971 [42] & $\mathrm{NR} /$ national survey & 10 \\
\hline Mexico (Guerrero state) 1997 [43] & 139/cave guides, peasants & $36.4-88.6$ \\
\hline Mexico (Guerrero, Queretaro, Tlaxcala state) 1994 [44] & $253 / \mathrm{NR}$ & $\begin{array}{l}2 \text { (Tlaxcala), } 83 \text { (Guerrero), } \\
53 \text { (Queretaro) }\end{array}$ \\
\hline Venezuela (Bolivar state) 2005 [45] & $182 /$ residents & 34 \\
\hline Venezuela (Bolivar state) 2004 [46] & 157/farmers & 42.7 \\
\hline Caribbean & 392/poultry farmers & 28.8 \\
\hline Cuba (Ciego de Avila)1992 [47] & NR & 4 \\
\hline Barbados $1981[48]$ & NR & 42 \\
\hline Trinidad 1981 & 454/residents & 7 Martinique, 4 Guadeloupe \\
\hline \multicolumn{3}{|l|}{$\begin{array}{l}\text { Martinique and Guadeloupe } 1972 \text { [49] } \\
\text { Africa }\end{array}$} \\
\hline Nigeria $1991[50]$ & 1087-226/healthy-hospital patients & $3.5(H c c), 3.0(H c d)$ healthy \\
\hline Nigeria (Anambra state) 1996 [51] & $\begin{array}{l}\text { 40/cave guides, traders, farmers } \\
620 / \text { farmers, palm oil workers }\end{array}$ & $\begin{array}{l}8.85(H c c), 6.6(H c d) \\
\text { hospital patients } \\
35(H c d), 8.8(H c d)\end{array}$ \\
\hline Somalia (Mogadishu and Jilib) 1979 [52] & $1014 / \mathrm{NR}$ & 0.3 \\
\hline $\begin{array}{l}\text { Uganda (Gulu, Jinja, Amudat, Fort Portal and } \\
\text { Kasese, Kampala, Pakwach) } 1970[53]\end{array}$ & 1144/residents & $0.4-12 \%$ \\
\hline
\end{tabular}

Hcc Histoplasma capsulatum var. capsulatum, Hcd Histoplasma capsulatum var. duboisii, NR not reported

In Thailand, the AIDS epidemic has been responsible of a dramatic upsurge of disseminated histoplasmosis with more than 1200 cases reported to the Ministry of Public Health from
1984 to 2010 [65]. A survey of histoplasmin sensitivity conducted in this country between 1966 and 1968 showed positivity rates of $7-14 \%$ in the northern region and $15-36 \%$ in 


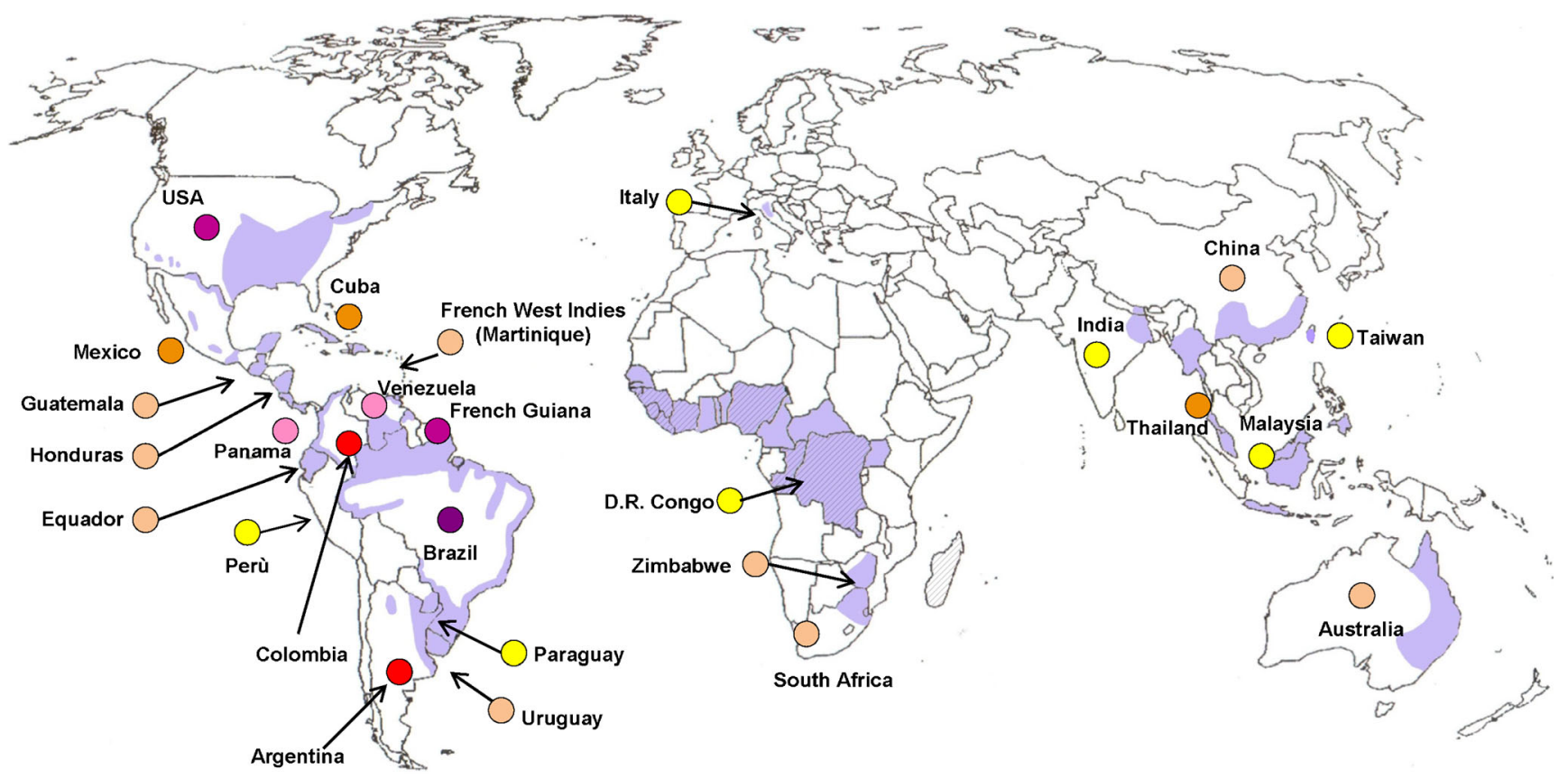

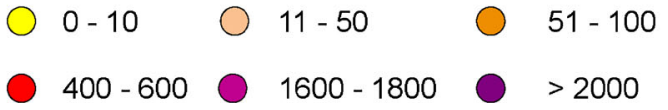

Fig. 1 Geographic distribution of Histoplasma capsulatum var. capsulatum (purple) and H. capsulatum var. duboisii (shadow area). The circles indicate the number of published cases of autochthonous

the southeast and southern regions [39], overlapping with areas containing Penicillium marneffei as determined by PCR [65].

Malaysia was the first country in Asia where H. capsulatum was successfully isolated from soil samples collected from bat-infested caves near Kuala Lumpur [66], and a survey of histoplasmin skin test sensitivity showed a prevalence of $10.5 \%$ in that country [54]. Cases of histoplasmosis have been recognized both among HIV-positive and HIV-negative patients as well as among subjects traveling to Malaysia [67, 68].

In India, histoplasmin sensitivity has been reported to be relatively high in Calcutta and Delhi (4.7-12.3 \%) [54] with most cases occurring in northeastern India in West Bengal and Assam states. Fungal isolation from soil has also occurred. An increasing number of cases of progressive disseminated histoplasmosis have been recognized in recent years in India among HIV-positive and/or diabetic patients, and some have suggested that histoplasmosis might be under-recognized due to being mistaken for tuberculosis [69]. In Australia, H. capsulatum has been cultured from different environmental sources (e.g., fowl yards and caves) in the states of Queensland and New South Wales. A recent review reported on 63 autochthonous cases from 1948 to 2009, including 11 with AIDS [70].

In South and Central America, large numbers of patients, many in persons infected with HIV, have been reported in
AIDS-associated histoplasmosis (via Scopus query). The majority of African cases have been observed outside Africa

Brazil, French Guiana, Argentina, Colombia, Venezuela, and Panama (Fig. 1) [14•, 71-74]. Importantly, a recently published map of histoplasmosis endemic areas in the region did not include French Guiana [75]. This would seem to have been an oversight as progressive disseminated histoplasmosis is the most common cause of AIDS-defining illness in that country with one retrospective study finding that $\sim 41 \%$ of HIV-positive hospitalized patients with fever and a CD4+ count $<200$ cells $/ \mu \mathrm{L}$ had disseminated histoplasmosis [14 $71,72,76 \bullet \cdot$. Similarly, more than $70 \%$ of patients with histoplasmosis included in a survey conducted in Colombia from 1992 to 2008 had HIV/AIDS [77]. Argentina has an area of endemicity for histoplasmosis in the northeastern part of the country [78].

In Brazil, histoplasmosis is highly endemic especially in the northern (Amazona, Roraima, Parà, Amapà, Cearà, Rio Grande do Norte, Bahia) and midwestern (Minas Gerais, Sao Paulo) states as well as the southeastern portions of the country. Histoplasmin positivity may be up to $\sim 90 \%$ in some areas (although positivity varies widely by study, Table 2 ) [36, 42, 44-46]. Moreover, a recent study from 1996 to 2006 showed 4.73 per 1000 deaths associated with AIDS that were due to histoplasmosis [79].

A study conducted in metropolitan Caracas, Venezuela, from 2000 to 2005 reported that AIDS was the risk factor in 
$33.5 \%$ of the 158 patients with histoplasmosis [73]. Histoplasmosis seems to be present in much of the region (Fig. 1) with HIV playing a crucial role in symptomatic infections.

The distribution of histoplasmosis in Africa is probably the most puzzling due to the lack of solid epidemiologic studies coupled with the limited laboratory capacity available in much of the continent $[52,58,59,80,81]$. Complicating matters, there is the coexistence of two varieties of the fungus: H. capsulatum var. duboisii ("African histoplasmosis") and H. capsulatum var. capsulatum on the continent. H. capsulatum var. duboisii has been primarily noted in Nigeria, Niger, Congo, Democratic Republic of Congo, and Uganda [80-82] although a few cases have also been observed in Madagascar, Chad, Ivory Coast, and Senegal [83-86]. Only 17 cases of H. capsulatum var. duboisii have been described among HIVinfected patients in Europe, with all being described as imported [12]. To the best of our knowledge, only two studies, from Zimbabwe and South Africa, respectively, described 12 and 14 persons coinfected with AIDS and H. capsulatum var. capsulatum $[87,88]$. The majority of published cases of histoplasmosis caused by $H$. capsulatum var. capsulatum among HIV-infected Africans were observed in Europe as imported infections [12, 13, 89]. Although one study in Tanzania has identified patients with febrile illnesses that were likely due to histoplasmosis, the majority of patients tested were HIVinfected [90]. In this study, the testing was done retrospectively as Histoplasma antigen testing, the most sensitive method of diagnosis, is not available in the region [90]. Patients originated from Democratic Republic of Congo, Congo, Liberia, Ivory Coast, Gambia, Uganda, Central African Republic, Guinea Bissau, and Senegal. In actuality, the majority of histoplasmosis cases in Africa are likely due to H. capsulatum var. capsulatum.

\section{Travel, Immigration, and Histoplasmosis}

The increasing number of persons traveling to endemic areas for tourism or international cooperation programs, or migrating for work is responsible of the growing number of reports of single or, more frequently, clusters of acute histoplasmosis. Numerous histoplasmosis cases among immigrants from Latin America and sub-Saharan Africa have occurred. Of particular importance in these populations are the potential to reactivate a previous infection when starting on immune suppressive therapy $[12,13,89,91]$.

Table 3 shows cases related to international travel but not immigration [91-106]. Sleeping outdoors or spelunking (where bats are present) is associated with the development of acute pulmonary histoplasmosis among tourists. However, in an outbreak, involving more than 200 US students in Acapulco, Mexico, which is the largest reported outbreak among travelers, the infection source was soil from a hotel's ornamental potted plants that had been fertilized with compost [92,
107]. More recently, an outbreak with a high attack rate (61\%) was observed among three mission groups that had traveled to El Salvador to renovate a church. Participation in dust-generating activities, such as digging or sweeping outdoors, was associated with an increased risk of symptomatic illness [97]. Although the number of reports of travelassociated histoplasmosis increased steadily in recent years (Table 3), likely many cases go unnoticed, especially if not presenting as a cluster of patients.

\section{Medical Immunosuppression and Histoplasmosis}

The number of patients receiving immunosuppressive and cyto-reductive therapies is increasing, particularly among patients who receive biologic medications to treat rheumatologic, gastrointestinal, or dermatologic diseases [36, 108•, 109•, $110^{\bullet}$. The fact that an intact immune system is important to prevent progressive dissemination of Histoplasma infection has been recognized $[9,14 \cdot]$, and so, these patients are more susceptible to histoplasmosis. For example, since as early as the 1950s, immune suppression in the form of Hodgkin's lymphoma was recognized as a risk factor allowing for progressive disseminated histoplasmosis [111].

Assi and colleagues conducted a large retrospective multicenter study of solid-organ transplant patients with histoplasmosis in known endemic areas, reviewing 152 cases that occurred at 24 centers from 2003 to 2010 [110•]. Among 152 histoplasmosis infections, all patients were receiving immunosuppressive medications, most were receiving calcineurin inhibitors (138 of 152) and one or two other medications with mycophenolate preparations and corticosteroids being the most common [110•]. Seventy-eight patients had kidney transplantation, 24 had liver transplantation, 22 were pancreas/kidney transplant recipients, 14 received heart transplants, 8 lung transplants, and 3 received pancreas transplants while 2 other individual patients had kidney transplant combined with either heart or lung, and 1 had a small-bowel transplant [110•]. In this population, urine Histoplasma antigen was the most sensitive test detecting 132 of 142 cases and while the median time from transplant to diagnosis was 27 months, $34 \%$ of cases occurred in the first years after transplant [110 $]$. Disseminated histoplasmosis occurred in $81 \%(122 / 152)$, and $10 \%(15 / 152)$ died [110 $]$.

Patients with autoimmune conditions such as rheumatoid arthritis are also at risk for progressive disseminated histoplasmosis if immunosuppressive medications are used. In a singlecenter study in an endemic area, 26 cases of patients with rheumatoid arthritis who were infected with Histoplasma were summarized. Progressive disseminated histoplasmosis was present in $46 \%(12 / 26)$ of patients with histoplasmosis [109•], 11 of the 12 patients were receiving multiple immune suppressive medications. Of the 26 total patients, 16 were 


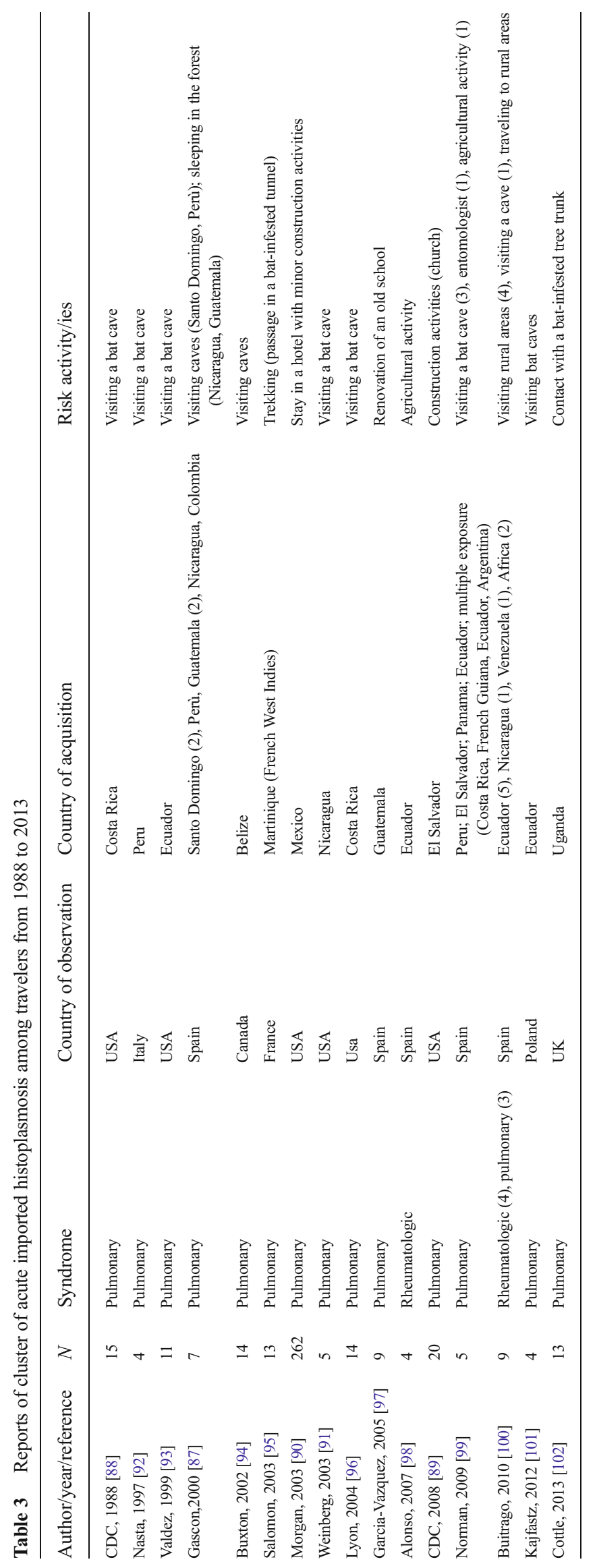


receiving methotrexate, 15 were receiving tumor necrosis factor (TNF)- $\alpha$ inhibitors, 15 were receiving corticosteroids (mean dose $9.1 \mathrm{mg} /$ day), 5 were receiving hydroxychloroquine, and 5 were receiving leflunomide [109•].

TNF- $\alpha$ inhibitors are particularly important as TNF- $\alpha$ is a key component of the granulomatous immune response to Histoplasma capsulatum [108•, 112]. As of 2010, 88 cases of histoplasmosis had been reported in patients using TNF- $\alpha$ inhibitors, a majority of cases were disseminated [108•]. While many cases come from endemic areas, cases outside of endemic areas have been reported as well [108•]. Cases continue to be reported, particularly in those patients using infliximab [108•]. As an example, in Indiana, of 19 reported cases related to TNF- $\alpha$ inhibitor use, 13 patients were using infliximab [108•]. A final note, paradoxical immune reconstitution inflammatory syndrome (IRIS) is a worsening of symptoms after successful microbiologic treatment upon improving a weakened immune system. Just as IRIS can occur in HIV-infected persons upon starting ART [113], IRIS can also occur when TNF- $\alpha$ inhibitors or other immunosuppressive medications are stopped [108•].

\section{Conclusions}

Histoplasmosis is much more widespread than was once thought, and current knowledge of its distribution is incomplete [30]. The AIDS pandemic has elucidated a worldwide risk for histoplasmosis, including areas previously unknown to be endemic. While ART access has improved to the point that histoplasmosis in the setting of HIV infection is rare in high-income countries, histoplasmosis remains a significant cause of AIDSassociated mortality in many parts of the world. Additionally, increased international travel and the use of immune suppressive medications are likely to lead to additional emergence of histoplasmosis infection from areas not previously known to be endemic, and the non-HIV-related incidence may continue to increase for progressive disseminated histoplasmosis. Thus, we believe histoplasmosis should be considered as a possible diagnosis in much of the world. Areas of higher density of exposure exist, and the consideration should be stronger if a patient has been to or lived in these locations. We advocate physicians considering disseminated histoplasmosis in patients with immune suppression, regardless of the location of the hospital to which the patient presents although the weight which one considers progressive disseminated histoplasmosis might vary widely depending on the patient's location. Currently, Histoplasma antigen testing is not available in many areas not previously thought to be endemic, and this may limit one's ability to diagnose the condition properly as it is currently the most sensitive method of diagnosis [32, 71, 110•]. We look forward to the day when we no longer hear a presentation that includes, "well, they haven't been to the Ohio River Valley so it can't be histoplasmosis" from trainees.

\section{Compliance with Ethics Guidelines}

Conflict of Interest Nathan C. Bahr, Spinello Antinori, L. Joseph Wheat, and George A. Sarosi declare that they have no conflict of interest.

Human and Animal Rights and Informed Consent This article does not contain any studies with human or animal subjects performed by any of the authors.

Funding Dr. Bahr is supported by National Institutes of Health Research Training Grant \#R25TW009345 awarded by the Fogarty International Center, the National Institute of Allergy and Infectious Disease, the National Institute of Mental Health, and Office of the Director as well as the National Institute of Allergy and Infectious Disease grant \#T32AI055433.

\section{References}

Papers of particular interest, published recently, have been highlighted as:

- Of importance

•• Of major importance

1. Wheat LJ, Freifeld AG, Kleiman MB, et al. Clinical practice guidelines for the management of patients with histoplasmosis: 2007 update by the Infectious Diseases Society of America. Clin Infect Dis. 2007;45(7):807-25.

2. Kuzma JF. Histoplasmosis; the pathologic and clinical findings. Dis Chest. 1947;13(4):338-44.

3. Christie A. Histoplasmosis and pulmonary calcification; geographic distribution. Am J Trop Med Hyg. 1951;31(6):742-52.

4. Edwards LB, Acquaviva FA, Livesay VT, Cross FW, Palmer CE. An atlas of sensitivity to tuberculin, PPD-B, and histoplasmin in the United States. Am Rev Respir Dis. 1969;99(4):1-132.

5. Londero AT, Fischman O, Ramos C. A critical review of medical mycology in Brazil 1946-1960. Mycopathol Mycol Appl. 1962;18:293-316.

6. Mochi A, Edwards PQ. Geographical distribution of histoplasmosis and histoplasmin sensitivity. Bull World Health Organ. 1952;5(3):259-91.

7. Sethi KK, Passi S. Histoplasmosis in India. A critical review. Mycopathol Mycol Appl. 1970;40(3):369-74.

8. Klugman HB, Lurie HI. Systemic histoplasmosis in South Africa. A review of the previous cases and a report of an additional casethe first successfully treated. S Afr Med J. 1963;37:29-31.

9. Knox KS, Hage CA. Histoplasmosis. Proc Am Thorac Soc. 2010;7(3):169-72.

10. Swartzentruber S, Rhodes L, Kurkjian K, et al. Diagnosis of acute pulmonary histoplasmosis by antigen detection. Clin Infect Dis. 2009;49(12):1878-82.

11. Medeiros AA, Marty SD, Tosh FE, Chin TD. Erythema nodosum and erythema multiforme as clinical manifestations of histoplasmosis in a community outbreak. N Engl J Med. 1966;274(8):41520.

12. Loulergue P, Bastides F, Baudouin V, et al. Literature review and case histories of Histoplasma capsulatum var. duboisii infections in HIV-infected patients. Emerg Infect Dis. 2007;13(11):1647-52.

13. Antinori S, Magni C, Nebuloni M, et al. Histoplasmosis among human immunodeficiency virus-infected people in Europe: report 
of 4 cases and review of the literature. Medicine (Baltimore). 2006;85(1):22-36.

14. Nacher M, Adenis A, Blanchet D, et al. Risk factors for disseminated histoplasmosis in a cohort of HIV-infected patients in French Guiana. PLoS Negl Trop Dis. 2014;8(1):e2638. This retrospective review convincingly shows an inverse risk of PDH with CD4+ T-cell count.

15. Ozols II, Wheat LJ. Erythema nodosum in an epidemic of histoplasmosis in Indianapolis. Arch Dermatol. 1981;117(11):709-12.

16. Rosenthal J, Brandt KD, Wheat LJ, Slama TG. Rheumatologic manifestations of histoplasmosis in the recent Indianapolis epidemic. Arthritis Rheum. 1983;26(9):1065-70.

17. Assi MA, Sandid MS, Baddour LM, Roberts GD, Walker RC. Systemic histoplasmosis: a 15-year retrospective institutional review of 111 patients. Medicine (Baltimore). 2007;86(3):162-9.

18. Wheat LJ, Batteiger BE, Sathapatayavongs B. Histoplasma capsulatum infections of the central nervous system. A clinical review. Medicine (Baltimore). 1990;69(4):244-60.

19. Jones PG, Cohen RL, Batts DH, Silva Jr J. Disseminated histoplasmosis, invasive pulmonary aspergillosis, and other opportunistic infections in a homosexual patient with acquired immune deficiency syndrome. Sex Transm Dis. 1983;10(4): $202-4$.

20. Kaur J, Myers AM. Homosexuality, steroid therapy, and histoplasmosis. Ann Intern Med. 1983;99(4):567.

21. Pasternak J, Bolivar R. Histoplasmosis in acquired immunodeficiency syndrome (AIDS): diagnosis by bone marrow examination. Arch Intern Med. 1983;143(10):2024.

22. Sathapatayavongs B, Batteiger BE, Wheat J, Slama TG, Wass JL. Clinical and laboratory features of disseminated histoplasmosis during two large urban outbreaks. Medicine (Baltimore). 1983;62(5):263-70.

23. Small CB, Klein RS, Friedland GH, Moll B, Emeson EE, Spigland I. Community-acquired opportunistic infections and defective cellular immunity in heterosexual drug abusers and homosexual men. Am J Med. 1983;74(3):433-41.

24. Wheat LJ, Slama TG, Zeckel ML. Histoplasmosis in the acquired immune deficiency syndrome. Am J Med. 1985;78(2):203-10.

25. Haggerty CM, Britton MC, Dorman JM, Marzoni Jr FA. Gastrointestinal histoplasmosis in suspected acquired immunodeficiency syndrome. West J Med. 1985;143(2):244-6.

26. Bartholomew C, Raju C, Patrick A, Penco F, Jankey N. AIDS on Trinidad. Lancet. 1984;1(8368):103.

27. Vithayasai P, Vithayasai V. Clinical manifestations of 174 AIDS cases in Maharaj Nakorn Chiang Mai Hospital. J Dermatol. 1993;20(7):389-93.

28. Geffray L, Veyssier P, Cevallos R, et al. [African histoplasmosis: clinical and therapeutic aspects, relation to AIDS. Apropos of 4 cases, including a case with HIV-1-HTLV-1 co-infection]. Ann Med Interne (Paris). 1994;145(6):424-8.

29. Wheat LJ, Connolly-Stringfield PA, Baker RL, et al. Disseminated histoplasmosis in the acquired immune deficiency syndrome: clinical findings, diagnosis and treatment, and review of the literature. Medicine (Baltimore). 1990;69(6):361-74.

30. Antinori S. Histoplasma capsulatum: more widespread than previously thought. Am J Trop Med Hyg. 2014;90(6):982-3.

31. Hajjeh RA, Pappas PG, Henderson H, et al. Multicenter casecontrol study of risk factors for histoplasmosis in human immunodeficiency virus-infected persons. Clin Infect Dis. 2001;32(8): 1215-20.

32. Myint T, Anderson AM, Sanchez A, et al. Histoplasmosis in patients with human immunodeficiency virus/acquired immunodeficiency syndrome (HIV/AIDS): multicenter study of outcomes and factors associated with relapse. Medicine (Baltimore). 2014;93(1): $11-8$.
33. Thompson MA, Aberg JA, Hoy JF, et al. Antiretroviral treatment of adult HIV infection: 2012 recommendations of the International Antiviral Society-USA panel. JAMA. 2012;308(4):387-402.

34. Ajello L, Zeidberg LD. Isolation of Histoplasma capsulatum and Allescheria boydii from soil. Science. 1951;113(2945):662-3.

35. Emmons CW. Isolation of Histoplasma capsulatum from soil. Public Health Rep. 1949;64(28):892-6.

36. Ajello L. Relationship of Histoplasma capsulatum to avian habitats. Public Health Rep. 1964;79:266-70.

37. Zhao B, Xia X, Yin J, et al. Epidemiological investigation of Histoplasma capsulatum infection in China. Chin Med J (Engl). 2001;114(7):743-6.

38. C.T. H. Histoplasmin and coccidiodin sensitivity among students in Taiwan. J Formos Med Assoc. 1953;4:549-54.

39. Jayanetra PP R, Satapathayawong B, Atichartrakarn V, Thianprasit M, Waropastrakul C, Poopaibul K, et al. The magnitude of the public health problem posed by the Mycoses. Part II: the lack of information. J Infect Dis Antimicrob Agents. 1987;4: 175-84.

40. Bezjak V, Farsey SJ. Prevalence of skin sensitivity to histoplasmin and coccidioidin in various Ugandan populations. Am J Trop Med Hyg. 1970;19(4):664-9.

41. Mangiaterra M, Alonso J, Galvan M, Giusiano G, Gorodner J. Histoplasmin and paracoccidioidin skin reactivity in infantile population of northern Argentina (1). Rev Inst Med Trop Sao Paulo. 1996;38(5):349-53.

42. Rodrigues MT, de Resende MA. Epidemiologic skin test survey of sensitivity to paracoccidioidin, histoplasmin and sporotrichin among gold mine workers of Morro Velho Mining, Brazil. Mycopathologia. 1996;135(2):89-98.

43. Carmona J. Analisis estadistico y ecologico-epidemiologico de la sensibilidad a la histoplasmina en Colombia 1950-1968. Antioquia Med. 1971;21:109-54.

44. Mok WY, Netto CF. Paracoccidioidin and histoplasmin sensitivity in Coari (state of Amazonas), Brazil. Am J Trop Med Hyg. 1978;27(4):808-14.

45. Diogenes MJ, Goncalves HM, Mapurunga AC, Alencar KF, Andrade FB, Nogueira-Queiroz JA. Histoplasmin and paracoccidioidin reactions in Serra de Pereiro. (Ceara StateBrazil). Rev Inst Med Trop Sao Paulo. 1990;32(2):116-20.

46. Zembrzuski MM, Bassanesi MC, Wagner LC, Severo LC. [An intradermal test with histoplasmin and paracoccidioidin in 2 regions of Rio Grande do Sul]. Rev Soc Bras Med Trop. 1996;29(1): $1-3$.

47. Cermeno JR, Cermeno JJ, Hernandez I, et al. Histoplasmine and paracoccidiodine epidemiological study in Upata, Bolivar state, Venezuela. Trop Med Int Health. 2005;10(3):216-9.

48. Pedroza-Seres M, Quiroz-Mercado H, Granados J, Taylor ML. The syndrome of presumed ocular histoplasmosis in Mexico: a preliminary study. J Med Vet Mycol. 1994;32(2):83-92.

49. Taylor ML, Perez-Mejia A, Yamamoto-Furusho JK, Granados J. Immunologic, genetic and social human risk factors associated to histoplasmosis: studies in the State of Guerrero, Mexico. Mycopathologia. 1997;138(3):137-42.

50. Cermeno JR, Hernandez I, Cermeno JJ, et al. Epidemiological survey of histoplasmine and paracoccidioidine skin reactivity in an agricultural area in Bolivar state, Venezuela. Eur J Epidemiol. 2004;19(2):189-93.

51. Suarez Fernandez MFACM, Estrada Ortiz A, Cisneiros Despaigne E. Reactividad a la histoplasmina en trabajadores de granajas avicolas en la provincia de Ciego de Avila, Cuba. Rev Inst Med Trop Sao Paulo. 1992;34:329-33.

52. Gugnani HC, Egere JU, Larsh H. Skin sensitivity to capsulatum and duboisii histoplasmins in Nigeria. J Trop Med Hyg. 1991;94(1):24-6. 
53. Wen FQ, Sun YD, Watanabe K, Yoshida M, Wu JN, Baum GL. Prevalence of histoplasmin sensitivity in healthy adults and tuberculosis patients in southwest China. J Med Vet Mycol. 1996;34(3): $171-4$.

54. Randhawa HS. Occurrence of histoplasmosis in Asia. Mycopathol Mycol Appl. 1970;41(1):75-89.

55. Bulmer AC, Bulmer GS. Incidence of histoplasmin hypersensitivity in the Philippines. Mycopathologia. 2001;149(2):69-71.

56. Hay RJ, White HS, Fields PE, Quamina DB, Dan M, Jones TR. Histoplasmosis in the eastern Caribbean: a preliminary survey of the incidence of the infection. J Trop Med Hyg. 1981;84(1):9-12.

57. de Lambert Cremeur Y, Drouhet E. [Aspects of histoplasmosis in French possessions in the Americas]. Bull Soc Pathol Exot Filiales. 1972;65(4):499-506.

58. Muotoe-Okafor FA, Gugnani HC, Gugnani A. Skin and serum reactivity among humans to histoplasmin in the vicinity of a natural focus of Histoplasma capsulatum var. duboisii. Mycopathologia. 1996;134(2):71-4.

59. Nuti M, Tarabini GC, Adorisio E, Zardi O. Histoplasmosis diffusion in Somalia: study of skin-test and serological survey. Biochem Exp Biol. 1979;15(2):111-7.

60.• Pan B, Chen M, Pan W, Liao W. Histoplasmosis: a new endemic fungal infection in China? Review and analysis of cases. Mycoses. 2013;56(3):212-21. This large review analyzed 300 cases of histoplasmosis in China over the preceding 30 years, most cases were PDH and most were related to advanced HIV.

61. Pan B, Deng S, Liao W, Pan W. Endemic mycoses: overlooked diseases in China. Clin Infect Dis. 2013;56(10):1516-7.

62. Chakrabarti A, Slavin MA. Endemic fungal infections in the AsiaPacific region. Med Mycol. 2011;49(4):337-44.

63. Wang TL, Cheah JS, Holmberg K. Case report and review of disseminated histoplasmosis in South-East Asia: clinical and epidemiological implications. Trop Med Int Health. 1996;1(1):3542.

64. Kikuchi K, Sugita T, Makimura K, et al. Is Histoplasma capsulatum a native inhabitant of Japan? Microbiol Immunol. 2008;52(9):455-9.

65. Norkaew T, Ohno H, Sriburee P, et al. Detection of environmental sources of Histoplasma capsulatum in Chiang Mai, Thailand, by nested PCR. Mycopathologia. 2013;176(5-6):395-402.

66. Ponnampalam J. Isolation of Histoplasma capsulatum from the soil of a cave in Central Malaya. Am J Trop Med Hyg. 1963;12: $775-6$.

67. Jing W, Ismail R. Mucocutaneous manifestations of HIV infection: a retrospective analysis of 145 cases in a Chinese population in Malaysia. Int J Dermatol. 1999;38(6):457-63.

68. Ohno H, Ogata Y, Suguro H, et al. An outbreak of histoplasmosis among healthy young Japanese women after traveling to Southeast Asia. Intern Med. 2010;49(5):491-5.

69. Gopalakrishnan R, Nambi PS, Ramasubramanian V, Abdul Ghafur K, Parameswaran A. Histoplasmosis in India: truly uncommon or uncommonly recognised? J Assoc Physicians India. 2012;60:25-8.

70. McLeod DS, Mortimer RH, Perry-Keene DA, et al. Histoplasmosis in Australia: report of 16 cases and literature review. Medicine (Baltimore). 2011;90(1):61-8.

71. Couppie P, Aznar C, Carme B, Nacher M. American histoplasmosis in developing countries with a special focus on patients with HIV: diagnosis, treatment, and prognosis. Curr Opin Infect Dis. 2006;19(5):443-9.

72. Huber F, Nacher M, Aznar C, et al. AIDS-related Histoplasma capsulatum var. capsulatum infection: 25 years experience of French Guiana. AIDS. 2008;22(9):1047-53.

73. Mata-Essayag S, Colella MT, Rosello A, et al. Histoplasmosis: a study of 158 cases in Venezuela, 2000-2005. Medicine (Baltimore). 2008;87(4):193-202.
74. Nacher M, Adenis A, Mc Donald S, et al. Disseminated histoplasmosis in HIV-infected patients in South America: a neglected killer continues on its rampage. PLoS Negl Trop Dis. 2013;7(11): e2319.

75. Colombo AL, Tobon A, Restrepo A, Queiroz-Telles F, Nucci M. Epidemiology of endemic systemic fungal infections in Latin America. Med Mycol. 2011;49(8):785-98.

76.• Vantilcke V, Boukhari R, Jolivet A, et al. Fever in hospitalized HIV-infected patients in Western French Guiana: first think histoplasmosis. Int J STD AIDS. 2014;25(9):656-61. This retrospective study analyzed HIV infected patients hospitalized with a febrile illness. The findings of the study are striking in that while $41 \%$ of these patients with CD4+ cell counts $<200$ had PDH, over $85 \%$ of those patients with CD4+ cell counts $<50$ had PDH. This is an incredibly important finding for this region.

77. Arango M, Castaneda E, Agudelo CI, et al. Histoplasmosis: results of the Colombian national survey, 1992-2008. Biomedica. 2011;31(3):344-56.

78. Corti MEN R, Esquivel P, Villafane MF. Histoplasmosis diseminada en paziente con SIDA: analisis epidemiologico, clinico, microbiologico e inmunologico de 26 pacientes. Enf Emerg. 2004;6:8-15.

79. Prado M, Silva MB, Laurenti R, Travassos LR, Taborda CP. Mortality due to systemic mycoses as a primary cause of death or in association with AIDS in Brazil: a review from 1996 to 2006. Mem Inst Oswaldo Cruz. 2009;104(3):513-21.

80. Gugnani HC, Muotoe-Okafor F. African histoplasmosis: a review. Rev Iberoam Micol. 1997;14(4):155-9.

81. Williams AO, Lawson EA, Lucas AO. African histoplasmosis due to Histoplasma duboisii. Arch Pathol. 1971;92(5):306-18.

82. Khalil MA, Hassan AW, Gugnani HC. African histoplasmosis: report of four cases from north-eastern Nigeria. Mycoses. 1998;41(7-8):293-5.

83. Coulanges P. Large-form histoplasmosis (H. duboisii) in Madagascar (apropos of 3 cases). Arch Inst Pasteur Madagascar. 1989;56(1):169-74.

84. Coulanges P, Raveloarison G, Ravisse P. [Existence of Histoplasma duboisii histoplasmosis outside continental Africa (apropos of the first Madagascar case)]. Bull Soc Pathol Exot Filiales. 1982;75(4):400-3.

85. Garcia-Guinon A, Torres-Rodriguez JM, Ndidongarte DT, Cortadellas F, Labrin L. Disseminated histoplasmosis by Histoplasma capsulatum var. duboisii in a paediatric patient from the Chad Republic, Africa. Eur J Clin Microbiol Infect Dis. 2009;28(6):697-9.

86. Oddo D, Etchart M, Thompson L. Histoplasmosis duboisii (African histoplasmosis). An African case reported from Chile with ultrastructural study. Pathol Res Pract. 1990;186(4): 514-7.

87. Gumbo T, Just-Nubling G, Robertson V, Latif AS, Borok MZ, Hohle R. Clinicopathological features of cutaneous histoplasmosis in human immunodeficiency virus-infected patients in Zimbabwe. Trans R Soc Trop Med Hyg. 2001;95(6):635-6.

88. KR P, Mosam A, Dlova NC NBS, Aboobaker J, Singh SM. Disseminated cutaneous histoplasmosis in patients infected with human immunodeficiency virus. J Cutan Pathol. 2002;29(4):21525 .

89. Inojosa $\mathrm{W}$, Rossi MC, Laurino $\mathrm{L}$, et al. Progressive disseminated histoplasmosis among human immunodeficiency virus-infected patients from West-Africa: report of four imported cases in Italy. Infez Med. 2011;19(1):49-55.

90. Lofgren SM, Kirsch EJ, Maro VP, et al. Histoplasmosis among hospitalized febrile patients in northern Tanzania. Trans R Soc Trop Med Hyg. 2012;106(8):504-7. 
91. Gascon J, Torres JM, Luburich P, Ayuso JR, Xaubet A, Corachan M. Imported histoplasmosis in Spain. J Travel Med. 2000;7(2): 89-91.

92. Morgan J, Cano MV, Feikin DR, et al. A large outbreak of histoplasmosis among American travelers associated with a hotel in Acapulco, Mexico, spring 2001. Am J Trop Med Hyg. 2003;69(6):663-9.

93. Alonso D, Munoz J, Letang E, et al. Imported acute histoplasmosis with rheumatologic manifestations in Spanish travelers. J Travel Med. 2007;14(5):338-42.

94. Garcia-Vazquez E, Velasco M, Gascon J, Corachan M, Mejias T, Torres-Rodriguez JM. [Histoplasma capsulatum infection in a group of travelers to Guatemala]. Enferm Infecc Microbiol Clin. 2005;23(5):274-6.

95. Nasta P, Donisi A, Cattane A, Chiodera A, Casari S. Acute histoplasmosis in spelunkers returning from Mato Grosso, Peru. J Travel Med. 1997;4(4):176-8.

96. Weinberg M, Weeks J, Lance-Parker S, et al. Severe histoplasmosis in travelers to Nicaragua. Emerg Infect Dis. 2003;9(10):1322-5.

97. Centers for Disease C, Prevention. Outbreak of histoplasmosis among travelers returning from El Salvador-Pennsylvania and Virginia, 2008. MMWR Morb Mortal Wkly Rep. 2008;57(50):1349-53.

98. Centers for Disease C. Cave-associated histoplasmosis - Costa Rica. MMWR Morb Mortal Wkly Rep. 1988;37(20):312-3.

99. Salomon J, Flament Saillour M, De Truchis P, et al. An outbreak of acute pulmonary histoplasmosis in members of a trekking trip in Martinique, French West Indies. J Travel Med. 2003;10(2):87-93.

100. Lyon GM, Bravo AV, Espino A, et al. Histoplasmosis associated with exploring a bat-inhabited cave in Costa Rica, 1998-1999. Am J Trop Med Hyg. 2004;70(4):438-42.

101. Buxton JA, Dawar M, Wheat LJ, et al. Outbreak of histoplasmosis in a school party that visited a cave in Belize: role of antigen testing in diagnosis. J Travel Med. 2002;9(1):48-50.

102. Valdez H, Salata RA. Bat-associated histoplasmosis in returning travelers: case presentation and description of a cluster. J Travel Med. 1999;6(4):258-60.

103. Buitrago MJ, Bernal-Martinez L, Castelli MV, Rodriguez-Tudela JL, Cuenca-Estrella M. Histoplasmosis and paracoccidioidomycosis in a non-endemic area: a review of cases and diagnosis. J Travel Med. 2011;18(1):26-33.

104. Cottle LE, Gkrania-Klotsas E, Williams HJ, et al. A multinational outbreak of histoplasmosis following a biology field trip in the Ugandan rainforest. J Travel Med. 2013;20(2):83-7.
105. Kajfasz P, Basiak W. Outbreak of pulmonary histoplasmosis involving a group of four Polish travellers returning from Ecuador. Int Marit Health. 2012;63(1):59-62.

106. Norman FF, Martin-Davila P, Fortun J, et al. Imported histoplasmosis: two distinct profiles in travelers and immigrants. J Travel Med. 2009;16(4):258-62.

107. Taylor ML, Ruiz-Palacios GM, del Rocio R-MM, et al. Identification of the infectious source of an unusual outbreak of histoplasmosis, in a hotel in Acapulco, state of Guerrero, Mexico. FEMS Immunol Med Microbiol. 2005;45(3):43541.

108. Hage CA, Bowyer S, Tarvin SE, Helper D, Kleiman MB, Wheat LJ. Recognition, diagnosis, and treatment of histoplasmosis complicating tumor necrosis factor blocker therapy. Clin Infect Dis. 2010;50(1):85-92. This study reviewed a relatively large number of cases of histoplasmosis associated with TNF- $\alpha$ inhibitor use, the majority of which were PDH. In addition, the study brings out the importance of considering immune reconstitution inflammatory syndrome with removal of the offending immunosuppressive agent.

109. Olson TC, Bongartz T, Crowson CS, Roberts GD, Orenstein R, Matteson EL. Histoplasmosis infection in patients with rheumatoid arthritis, 1998-2009. BMC Infect Dis. 2011;11:145. This single center study make two important points. Patients with rheumatoid arthritis are at risk of histoplasmosis even if on minimal or no immune suppression; however, if a patient with rheumatoid arthritis is on immune supressive therapy, the likelyhood of the infection progressing to PDH is much higher.

110. Assi M, Martin S, Wheat LJ, et al. Histoplasmosis after solid organ transplant. Clin Infect Dis. 2013;57(11):1542-9. This large retrospective multi-center study of solid organ transplant patients with histoplasmosis. The study encompassed 152 infections at 24 centers and characterized transplant type, immune suppression used, the type of infection as well as mortality in this population.

111. Ende N, Pizzolato P, Ziskind J. Hodgkin's disease associated with histoplasmosis. Cancer. 1952;5(4):763-9.

112. Deepe Jr GS, Wuthrich M, Klein BS. Progress in vaccination for histoplasmosis and blastomycosis: coping with cellular immunity. Med Mycol. 2005;43(5):381-9.

113. Marianelli LG, Frassone N, Marino M, Debes J. Immune reconstitution inflammatory syndrome as histoplasmosis osteomyelitis in South America. AIDS. 2014;28(12):1848-50. 